\title{
Casting off towards a blue future
}

Written by: Lorna Siggins, Marine and Western Correspondent, The Irish Times

Last update: 3 March 2020

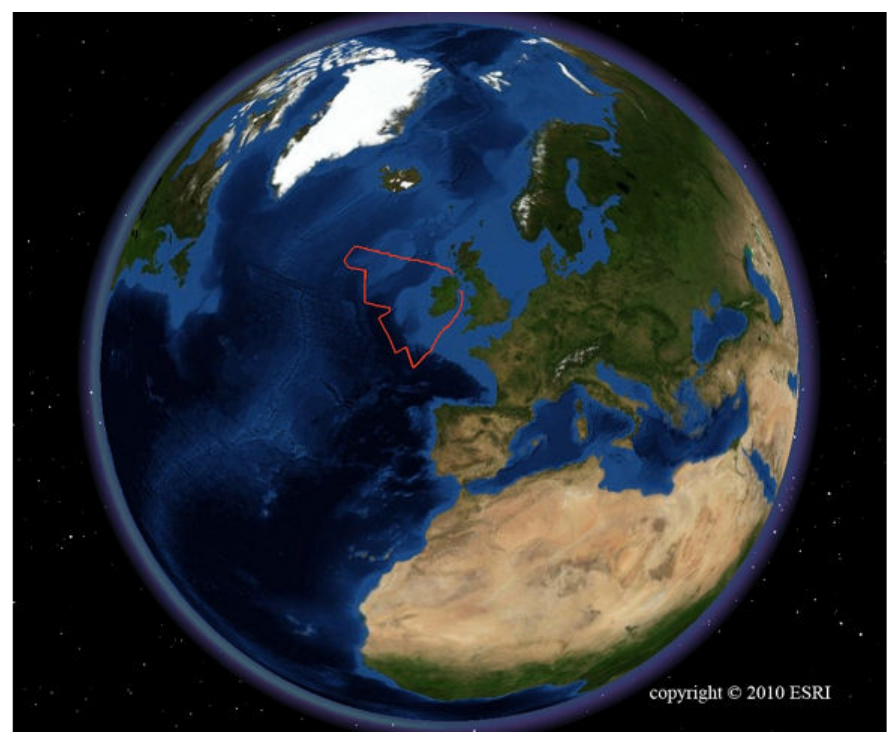

Open any atlas, look at any globe, and Ireland appears as a small green island on Europe's Atlantic rim. But in fact, Ireland's territory is almost the size of Germany, and mostly blue.

If you asked Vice-Admiral Mark Mellett, the current head of the Irish military what sovereign territory he is responsible for, he would point to a 1 million square kilometre horizon, equivalent to ten times the land size, with some $93 \%$ of it underwater.

Mr Mellett, the first Naval Service officer to hold such a senior position in the Irish defence forces, would also wax lyrical about the economic opportunities offered by a sea area with some of the most biologically rich fishing grounds and some of the most energetic waves in the north-east Atlantic-and with potential for "trillions" of euros in hydrocarbons and renewable energy.

Over 40 years after Ireland traded access to its waters by European fleets for EU concessions for the agricultural sector, Mr Mellett's appointment in September reflects a very different approach by the Irish state to the marine. Such was the lack of enthusiasm in opportunities beyond the coast during the 1970s that those appointed to marine affairs would joke about being responsible for "fish and ships". 
No longer. Simon Coveney, current holder of that portfolio, is a keen sailor whose passion for the sea led to an integrated marine plan, Harnessing Our Ocean Wealth, published in 2012. It has a target of doubling the value of Ireland's "blue economy" by 2030 .

Parallel with this is the EU's own blue growth initiative, which recognises the need for considerable investments in science and technology to develop the sea-based economy to its full potential. It has identified five key sectors: blue energy, aquaculture, maritime coastal and cruise tourism, marine mineral resources, and marine biotechnology.

Meanwhile, the European Marine Board, representing key research institutions across the community, has recently identified the need for greater focus on the deep sea environment, below 200 metres. "Earth's inner space" of cold and dark abyssal plains and hydrothermal vent ecosystems may hold secrets to the origins of life, it says.

Mr Coveney's ambition is to ensure that Ireland secures a stake in what he describes as the "blue century". A report published by the Socio-Economic Marine Research Unit of NUI Galway, a university on the west coast, during the summer of 2015 noted that Ireland's maritime sector was performing better on average than the general economy, at a growth rate of 8-9\% between 2010 and 2014.

Marine-related employment rose from 17425 to 18480 full-time equivalents in 2012-14, with turnover of about $€ 4.5$ billion a year .

Marine-related employment rose from 17425 to 18480 full-time equivalents in Developing the marine economy is a long game. Irish scientists are already heavily involved in 2012-14, with turnover of national and international projects, ranging from seabed mapping to locating and protecting about €4.5 billion a cold water coral on the continental shelf to measuring ocean acidification caused by the rise in carbon dioxide levels in the atmosphere.

Some have worked with the European Space Agency on monitoring and forecasting of jellyfish blooms that can have a negative impact on fish farms, for instance. Other projects include research into wave and tidal energy to using sail power for propelling naval ships. Organic cod farming is also under development.

Research is focused at NUI Galway and at University College Cork, which is part of an Irish maritime energy research cluster involving Cork Institute of Technology and the Naval Service. The state-run Marine Institute in Galway is designed to play an overarching role in co-ordination.

Raising the funds for this research and scientific work is a challenge, whatever the long-term benefits. EU and Irish public funding geared towards applied research tends to favour valid projects with immediate job creation prospects and privatesector funding. Yet as the OECD argues, a truly innovative climate needs public 
funding for basic research. Professor Colin Brown, the director of NUI Galway's Ryan Institute, gives an example from the domain of earth observation. He explains that high-frequency radars geared to monitor the sea surface can measure wave heights and sea surface currents. These data can then be input into hydrodynamic computer models with meteorological data, such as wind speeds, and can then be used to forecast the energy available. Such innovations for smart energy use also have the potential to predict flooding and sea surges.

Prof Brown believes a real breakthrough is in the offing, and though he compliments the Irish government on its investment in marine renewable energy innovation, he believes climate change should figure more strongly in their funding considerations.

His vision would have found hearty support from another leading advocate of the sea, the historian John de Courcy Ireland, who died 10 years ago in April. Dr Ireland ploughed the seas as a young man, working for several merchant navies, and was later decorated by countries around the world for his services to the sea, including the likes of France, Spain and Argentina. Dr Ireland always praised the hardworking small ports and family-run shipping firms along Ireland's coast, but decried the Irish people's generally indifferent attitude towards the sea and their preference for land on an island where beef forms more of the national diet than fish or seafood (most of which is exported). Some blame this paradox on a deeply rooted fear among some communities of the hostile oceans that for years claimed so many lives when fishers were dependent on small canvas boats called currachs, others on the fact that fish on Fridays was seen a penance rather than a pleasure, and still others on the political influence of the Irish livestock industry.

These attitudes are changing, and Dr Ireland lived just long enough to see the development of a multimillion-euro fishing industry in ports such as Killybegs in County Donegal, the founding of a maritime museum near his home in Dublin, and the beginnings of marine tourism on an Atlantic rim that is now a magnet for surfers worldwide.

Though Irish proverbs like "the sea receives its own" (originally in Gaelic Irish) reflected that historical fatalism, Dr Ireland also noted more positive sayings. "The person who owns a boat will one day find their reward" was one that he particularly liked to share with political leaders. Recent progress in Ireland's blue economy suggests that his subtle message has finally been heeded.

\section{References}

De Courcy Ireland, John (1992), Ireland's Maritime Heritage, An Post, Dublin http://www.amazon.fr/Irelands-maritime-heritage-Courcy-Ireland/dp/ 1872228097

Marine Co-ordination Group (2012), Harnessing Our Ocean Wealth: An Integrated Marine Plan for Ireland http://www.ouroceanwealth.ie/about-plan 
European Marine Board (2015), "Delving Deeper: How can we achieve sustainable management of our deep sea through integrated research?”, EMB Policy Brief No 2, November http://www.marineboard.eu/ 